\title{
TITLE INDEX OF VOLUME 24
}

\section{EDITORIALS $1,41,141,205,293$}

\section{UNITED NATIONS ACTIVITIES}

\section{UN/GA}

- Secretary-General's Report

- Forty-Eighth Session

- Fish Stocks : Revised Negotiating Text

- Convention on Fish Stocks?

- Report of the Secretary-General

$\mathrm{UN} / \mathrm{CSD}$

- CSD Holds Second Session

- Sustainable Development and International Law

UN/ECE

- Supervision of Non-Compliance - Draft Sulphur Protocol -

- Sulphur Protocol Adopted

- "Environment for Europe" Process

UN/ILC

- Non-navigational Uses of International Watercourses

\section{UN/SIDS}

- Small Island Developing States : PrepCom Meets

- Small Island Developing States : Programme UN of Action Adopted

- Transport of Dangerous Goods

- Environmental Crimes

UNCLOS

- Agreement on Deep Seabed Mining

UNCTAD

- ITTA Successor Agreement

UNEP

- The Basel Convention : A Global Approach for the Management of Hazardous Wastes (Iwona Rummel-Bulska)

- Effectiveness of Regional Seas Agreements (David Miller)

- Export of Hazardous Wastes

- Review of Montreal Guidelines
- Code of Ethics for Chemicals Trade

306

UNEP/GC

43 - Council Adopts GEF II Instrument

225

142

Africa

- International Wildlife Task Force

307

Climate Change Convention

- Preparations for the First Conference of the Parties (Sebastian Oberthür)

\section{CSD}

- Intersessional Ad Hoc Working Groups

ECOSOC

231 IAEA

231 - Convention on Nuclear Safety

ILC/46th Session

230 - Major Progress on International Law 294

IMO

- Draft Convention on Liability and

- Identification Technology for Commercial Shipping ?

INC/Desertification

- Convention Proposals Discussed 8

- More than Half-way?

- Desertification : Progress at Fourth Session 145

- Desertification Convention Finalised 229

304 Ozone Layer

- Budgets Approved

World Bank

- GEF Restructuring : Decisions Postponed

Dryland Management

Environment for Europe : First Session

Summit for Social Development :

Second Session

147 International Conference on Population and

\section{OTHER INTERNATIONAL DEVELOPMENTS}

\section{Basel Treaty}

- Control of Hazardous Wastes Strengthened

Bonn Convention

- Outcome of the Fourth Meeting of the Conference of the Parties

\section{EAPPCED II}

251 - "Phuket Declaration" of Parliamentarians FFDC

251 - Forest Declaration 


\section{GATT/WTO}

- Tuna Embargo ; US Action Condemned GEF

- Restucturing Instrument

ICC

- Environmental Charter

ICRC

- Protection of the Environment in Time of Armed Conflict

IUCN/GA

- Caring for the Earth and its People

In the Light of UNCED

- Permanent Sovereignty over Natural Resources (Ayesha Diaz)

World Bank

- Independent Panel

Pacem in Maribus XXI (Elisabeth Mann Borghese)

Global Human Security

Global Human Security (Johannes Rau)

Information and Knowledge Inputs :

312

156

187

25

85

157
Combatting Desertification in Africa and Transboundary Air Pollution in Europe (Dejen Abate/Shahid Akhtar)

Need for an International Court for the Environment? - Underdeveloped Legal Protection for the Individual in Transnational Litigation (Alfred Rest)

Elizabeth Haub Prize 1993

L'environnement face à l'Organisation

Mondiale du Commerce

(Wilfried Lang)

Aircraft Engine Emissions and Noise (R.I.R.Abeyratne)

Global Forests

Antarctic Treaty Liability Annex : Progress Up to Now

Programme Priorities Set

Implementing the Principles of Intergenerational Equity and Responsibility (Alfred Rest)

\section{REGIONAL AFFAIRS}

\section{Arctic Region}

- Agreement on Monitoring

Asia

- Qatar International Law Conference

Council of Europe

- Demographic Change and Sustainable Development

EC

- Recent Developments

European Court

- Italy Comdemned for Non-Compliance Waste Oils

- Environmental Crime

- EP Waste Attempt Rejeted

\section{European Union}

27 - Safety at Sea

EU

260 - Greek proposal for Energy/CO $/ \mathrm{CO}_{2}$ Tax

190

- Air and QWater Quality

North Sea

- Objectives Inadequate

Norway and the European Union (H.Gwilliam and G.Lugten)

Southern Africa/EU

94 - Berlin Declaration

321 USA/Canada/Mexico

- NAFTA : Environmental Co-operation

\section{NATIONAL AFFAIRS}

\author{
China/Japan \\ - Co-operation on Environment \\ Germany \\ - Environmental Performance Review \\ - Waste Recycling \\ India \\ - Closure of Industrial Plants
}

Italy

$\begin{aligned} 190- & \text { Cession of State Properties and the } \\ & \text { Law on Privatisation } \\ 29 & \text { (Gianpaolo Peccolo) } \\ 30 & -\quad \begin{array}{l}\text { Protected Areas and the "Caracas } \\ \text { Action Plan" }\end{array} \\ 190 & \text { (Andrea Simoncini) }\end{aligned}$




\section{Japan/Russia}

- Dumping of Nuclear Waste

Netherlands

- Environmental Covenants

- Dutch Environmental Covenant for the Oil and Gas Producing Industry : A Valuable Policy Instrument (Rob Gerits and Jules Hinssen)

\section{Norway}

- Whaling Dispute

Russia

- The trials of the First Public Interest

Environmental Law Firm

33

191
UK

- Bank Liability for Pollution? 34

- National Sustainable Development Plan 104

- Environmental Performance Criticised 191

- Successful Prosecutions 191

- Compensation for Radiologically-induced 263 Cancer : A Review (Christopher E.Miller)

- Biodiversity Convention Ratified

US

- Environment Plan

\section{SELECTED DOCUMENTS}

UN

- Report of the Secretary-General on the Work of the Organisation

- Elaboration of an International Convention to Combat Desertification in Countries experiencing Serious Drought and/or Desertification, particularly in Africa

- Preliminary Draft Second Sulphur Protocol

- Law of the Sea - Implementation of Part XI -

UN/GA

- Forty-Eighth Session (First Part)

- Decisions and Resolutions -

- Report of the Secretary-General on the Work of the Organisation

- Environment and Sustainable Development : Implementation of Decisions and Recommendations of UNCED

UN/CSD

- Second Session : Decisions

- Chairmans's Summary of the High-level Segment

UN/ECE

- Compliance and Sulphur Protocol

- Compliance : Montreal Protocol

- Long-Range Transboundary Air Pollution : Oslo Ministerial Declaration

UN/ECOSOC

- The Role of Criminal Lawin the Protection of the Environment

UNEP

- Workshop on Dryland Management

- Recommendations for Follow-Up Action -

- Code of Ethics on the International Trade in Chemicals

UNCTAD

- ITTA Successor Agreement
- Ad Hoc Working Group on Trade, Environment and Development

- Terms of Relevance -

Basel Convention

- Control on Transboundary Movements of Hazardous Wastes

Doha Declaration

Priorities for Progressive Development of International Law in the UN Decade of International Law to meet the Challenges of the 21st Century

\section{EAPPCED II}

- The Second East Asia \& Pacific Parliamentarians Conference

\section{ECE/CEP}

- Recommendations to ECE Governments

- Intergovernmental Working Group on EU Global Forests - Report of the First Meeting -

FFDC

Energy/CO 2 Tax

- The Delhi Declaration on Forests

GEF

133

331

- Instrument for the Establishment of the Restructured Global Environment Facility - Extracts -

ICAO

284 - Environmental Impact of Civil Aviation on the Upper Atmosphere

ICEL

121 - Need for an International Court for the Environment? - Draft Resolution ICRC

- Protection of the Environment in Times of Armed Conflict 
ILC

- The Law of Non-Navigational Uses of International Watercourses

INCD

- Desertification Convention
South Africa/EU

335 - Extracts from the Berlin Declaration

366 World Bank

- The World Bank Inspection Panel

\section{AUTHOR INDEX OF VOLUME 24}

Abate, Dejen

Abeyratne, R.I.R.

Akhtar, Shahid

Diaz, Ayesha

Gerits, Rob

Gwilliam, H.

Hinssen, Jules

Lang, Wilfried

Lugten, G.
71 Mann-Borghese. Elisabeth

19

235 Miller, Christoph E.

Miller, David

263

71

157

323

254

323

235

254

Oberthür, Sebastian

Peccolo, Gianpaolo

Rau, Johannes

Rest, Alfred

Rummel-Bulska, Iwona

Simoncini, Andrea
56

299

30

70

173,314

13

95 